\title{
Morphometric and densitometric characteristics of the brainstem locus coeruleus neurons nuclei in rats with experimental arterial hypertension
}

\author{
O. V. Hancheva ${ }^{*}$, M. V. Danukalo ${ }^{A-D}, 0$. V. Melnikova ${ }^{\mathrm{E}}$
}

Zaporizhzhia State Medical University, Ukraine

A - research concept and design; B - collection and/or assembly of data; C - data analysis and interpretation; D - writing the article; $\mathrm{E}$ - critical revision of the article; $\mathrm{F}$ - final approval of the article

Key words: densitometry, cariometry, brainstem, locus coeruleus, arterial hypertension, rats.

Pathologia 2019; 16 (1), 4-8

DOI:

10.14739/2310-1237.

2019.1.166145

*E-mail:

gancheva@zsmu.pp.ua
The aim of our study was to establish the morphodensitometric features of locus coeruleus (LC) neurons nuclei in the brain stem of rats with arterial hypertension of various origin (essential - SHR and endocrine-salt hypertension (ESH)).

Matherials and methods. The study was carried out on 30 mature male rats: 10 control Wistar rats, 10 Wistar rats with modeled endocrine-salt $\mathrm{AH}$ (ESH) and 10 spontaneously hypertensive rats (SHR) with genetically determined hypertension. The histochemical method of staining with gallocyanine-chrome alum by Einarson was used for the evaluation of morphodensitometric characteristics of the neurons nuclei: the nucleus area, the content and concentration of nucleic acids (NA) in the nucleus.

Results. It was found that the highest indices were observed in rats of the SHR line while in rats with ESH the content, RNA concentration and nucleus area decreased. In SHR rats with essential hypertension high synthetic activity was observed in the LC neurons with an increase of the content and concentration of NA.

Conclusions. Morphometric and densitometric characteristics of the of the brain stem LC in AH depend on the etiological factor and pathogenesis of hypertension. In essential AH of SHR there is a high synthetic activity in the brainstem LC neurons nuclei along with an increase in the content and concentration of NA. In symptomatic AH in rats with $\mathrm{ESH}$, on the contrary, the structure activity is decreased and characterized by the reduction in nucleus size and NA content in it.
Ключові слова: Аенситометрія, каріометрія, мозковий стовбур, locus coeruleus, артеріальна гіпертензія, щури.

Патологія. - 2019. -

T. 16, № 1(45). -

C. 4-8

\section{Морфоденситометричні характеристики ядер нейронів блакитної пмями стовбура мозку щурів при експериментальній артеріальній гіпертензії}

\section{О. В. Ганчева, М. В. Аанукало, О. В. Мельнікова}

Мета роботи - встановити особливості морфоденситометричних параметрів ядер нейронів блакитної плями стовбура мозку щурів при артеріальній гіпертензії різного генезу (есенціальній - щури лінії SHR, ендокринно-сольовій).

Матеріали та методи. Дослідження виконали на статевозрілих 30 щурах-самцях, серед них 20 тварин лінії Wistar, яких поділили на дві групи: 10 - контроль, 10 - змодельована ендокринно-сольова АГ (ЕСГ); 10 щурів лінії SHR із генетично детермінованою АГ. Для дослідження морфоденситометричних характеристик ядер нейронів блакитної плями (БП) використовували гістохімічний метод забарвлення галоціанін-хромовими галунами за Ейнарсоном. Оцінювали такі показники ядер нейронів: площа ядра, вміст і концентрація нуклеїнових кислот (НК) в ядрі.

Результати. Встановили, що найвищі показники спостерігали в щурів лінії SHR, а в щурів з ЕСГ показники вмісту, концентрації НК і площі зменшилися.

Висновки. Морфоденситометричні характеристики нейронів БП стовбура мозку при артеріальній гіпертензії залежать від її етіологічного чинника та патогенезу. При есенціальній АГ у щурів лінії SHR спостерігали високу синтетичну активність в ядрах нейронів БП стовбура мозку зі збільшенням вмісту та концентрації НК. При симптоматичній АГ у щурів 3 ЕСГ активність структури знижується та характеризується зменшенням вмісту НК і площі ядра нейрона.
Ключевые слова: Аенситометрия, кариометрия, ствол мозга, locus coeruleus, артериальная гипертензия, крысы.

Патология. - 2019. T. 16, № 1(45). C. 4-8

\section{Морфоденситометрические характеристики ядер нейронов голубого пятна ствола мозга крыс при экспериментальной артериальной гипертензии}

\section{О. В. Ганчева, М. В. Аанукало, О. В. Мельникова}

Цель работы - установить особенности морфоденситометрических параметров ядер нейронов голубого пятна ствола мозга крыс при артериальной гипертензии различного генеза (эссенциальной -крысы линии SHR, эндокринно-солевой).

Материалы и методы. Исследование проведено на половозрелых 30 крысах-самцах, среди которых 20 животных линии Wistar, разделенных на две группы: 10 - контроль, 10 - со смоделированной эндокринно-солевой АГ (ЭСГ); и 10 крыс линии SHR с генетически детерминированной АГ. Для исследования морфоденситометрических характеристик ядер нейронов голубого пятна (ГП) использовали гистохимические методы окраски галлоцианин-хромовыми квасцами по Эйнарсону. Оценивали следующие показатели ядер нейронов: площадь ядра, содержание и концентрация нуклеиновых кислот (НК) в ядре. 
Результаты. В ходе исследования установили, что наиболее высокие показатели наблюдали у крыс линии SHR; y крыс с ЭСГ показатели содержания, концентрации РНК и площади уменьшились.

Выводы. Морфоденситометрические характеристики нейронов ГП ствола мозга при артериальной гипертензии зависят от ее этиологического фрактора и патогенеза. При эссенциальной АГ у крыс линии SHR отмечена высокая синтетическая активность в ядрах нейронов ГП ствола мозга с увеличением содержания и концентрации НК. При симптоматической АГ у крыс с ЭСГ активность структуры снижается и характеризуется уменьшением содержания НК и площади ядра нейрона.

Arterial hypertension $(\mathrm{AH})$ is one of the most common human chronic diseases. In Ukraine, according to epidemiological studies, age-standardized prevalence of hypertension in the urban population is $29.6 \%$ both for men and women. Among the rural population the incidence of hypertension is higher $-36.3 \%$, in particular $37.9 \%$ for men and $35.1 \%$ for women. Also, the interest in this disease can be explained by its widespread, serious and frequent complications which lead to high lethality [1]. Considering the abovementioned, the relevance of this nosology comprehensive study of is beyond any doubt. Today, for further understanding of hypertension pathogenesis, the research of the functional activity of neurons which are the key centers of blood pressure (BP) regulation in $\mathrm{AH}$ of various origin is the object of many scientific studies [2-4]. One of such important central regulators of $\mathrm{BP}$ is locus coeruleus (LC) - the noradrenergic brainstem structure, the functional variety of which is well described in the scientific literature [5,6]. Indeed, it has been reported that its neuronal system plays an important role in the regulation of the sleep-wake cycle and $\mathrm{BP}$, facilitates learning and memorizing processes as well as regulates pain sensitivity $[7,8]$. Also mechanisms of LC implication in BP control are described in various scientific works $[9,10]$.

However, the issue of LC structure functional capacity in arterial hypertension of different etiopathogenesis, in our opinion, is not sufficiently covered in the scientific literature. The morphofunctional state of the neuron could be measured indirectly, without applying direct electrophysiological methods, by analyzing the nucleus size and nucleic acids (NA) concentration in it, which demonstrates the overall synthetic activity and functional state of the cell $[11,12]$. Therefore, this study is based on the corresponding histochemical method application.

\section{Objective}

To determine the peculiarities of morphometric and densitometric parameters of brainstem LC neurons nuclei in rats with $\mathrm{AH}$ of various genesis (essential - SHR and endocrine-salt hypertension).

\section{Materials and methods}

The study was carried out on 30 mature male rats: 10 control Wistar rats, 10 Wistar rats with modeled endocrine-salt $\mathrm{AH}(\mathrm{ESH})$ and 10 spontaneously hypertensive rats (SHR) with genetically determined hypertension. To date, the SHR have been widely viewed as one that most closely corresponds to human essential hypertension [13].

ESH was induced by intraperitoneal injection of prednisolone (twice a day for 30 days: at $7 \mathrm{am}-2 \mathrm{mg} / \mathrm{kg}$, at $20 \mathrm{pm}-4 \mathrm{mg} / \mathrm{kg}$ ) with $5 \mathrm{ml}$ of $2.3 \% \mathrm{NaCl}$ solution forced intake) [14]. This model is similar to the secondary human $\mathrm{AH}$ in terms of endocrine abnormalities. The mean $\mathrm{BP}$ on the $21^{\text {st }}$ day of modeled ESH was $137.8 \pm 5.0 \mathrm{~mm}$ $\mathrm{Hg}$, while it was $83.8 \pm 5.0 \mathrm{~mm} \mathrm{Hg}$ in the control. In SHR $\mathrm{BP}$ was $125.8 \pm 5.0 \mathrm{~mm} \mathrm{Hg}$ throughout the monitoring period. At the end of experiment the animals were immediately sacrificed via decapitation after being anesthetized with aethaminalum-natrium at a dose of $40 \mathrm{mg} / \mathrm{kg}$ body weight intraperitoneally. The study object in experimental animals was the medulla oblongata. The experimental

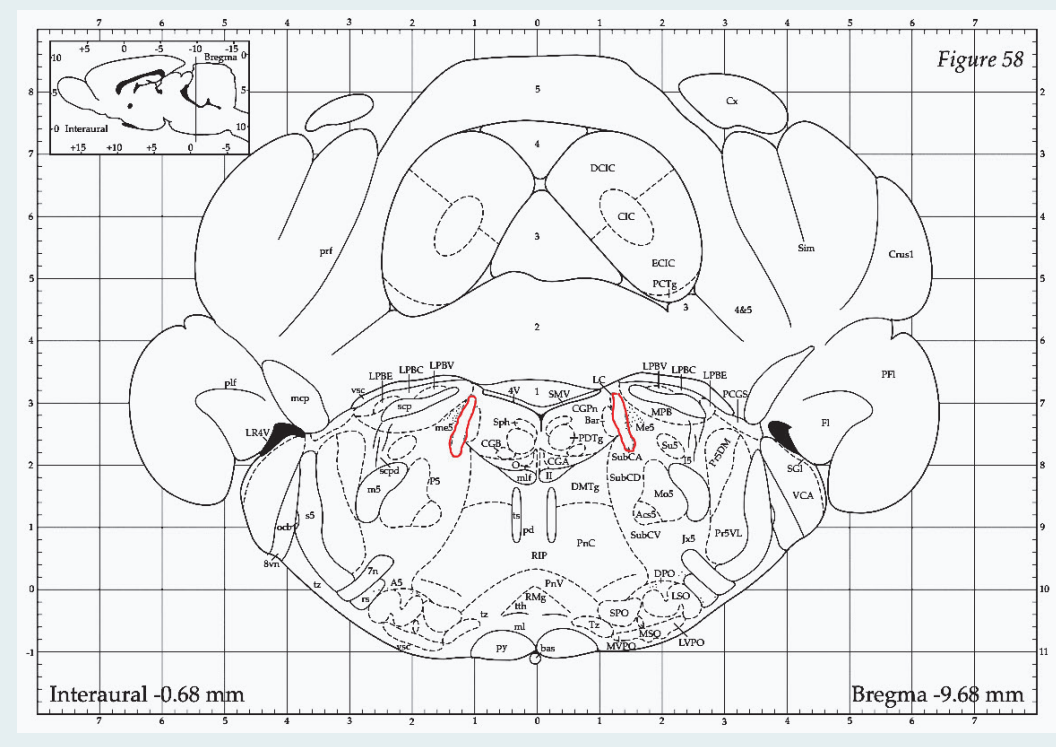

Fig. 1. Topography of the brainstem LC structure in rats (by Paxinos $\mathrm{G}$. The rat brain in stereotaxic coordinates / G. Paxinos Ch. Watson - Academic Press, 1998. - P. 474.). 

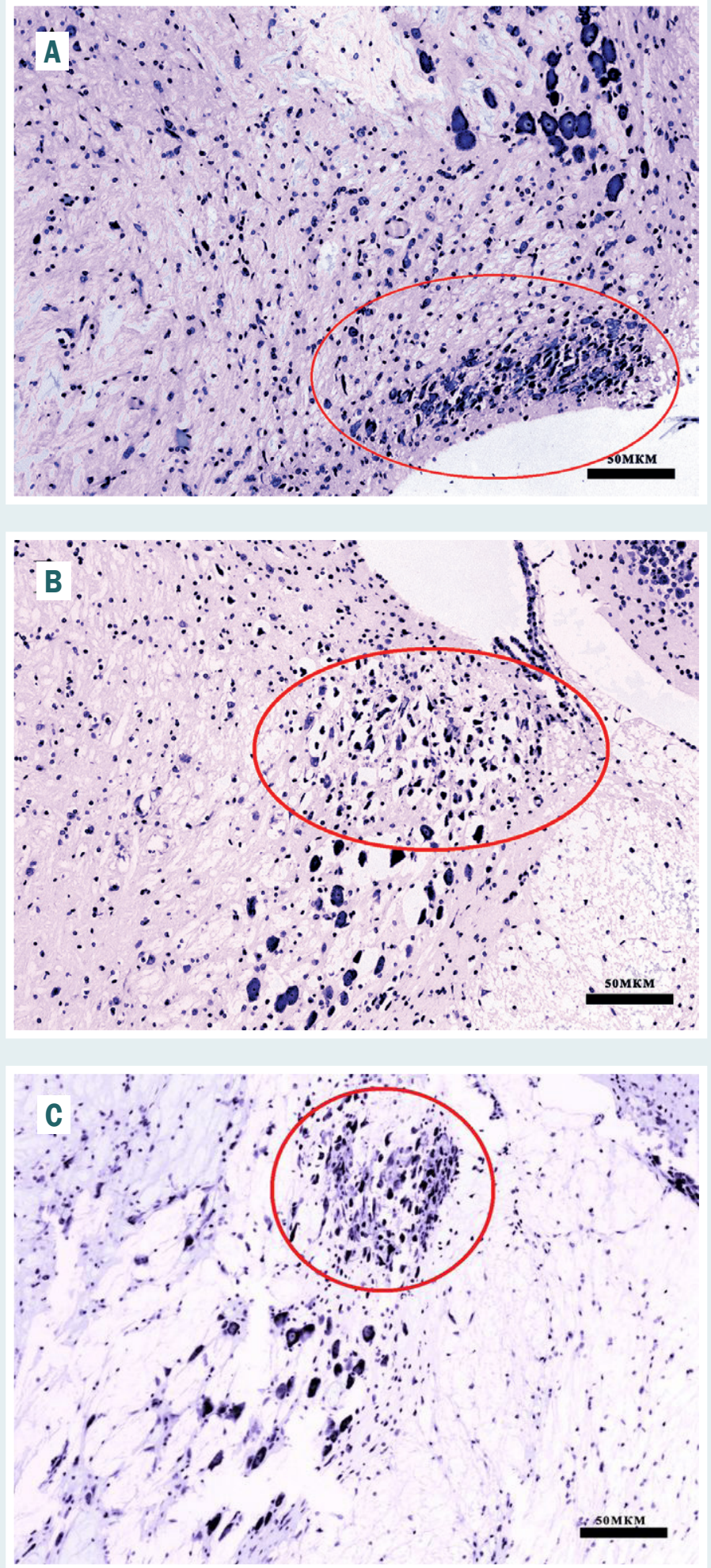

Fig. 2. Neurons of LC in rats of the experimental groups (stained with gallocyanine-chrome alum by Einarson):

A: in the control group rats; B: in the SHR; C: in the rats with induced ESH.

part of the study was carried out exactly in accordance with the National "General Ethical Principles of Animal Experimentation" (Ukraine, 2001), in agreement with the Directive 2010/63EU of the European Parliament and of the Council of 22 September 2010 on the protection of animals used for scientific purposes.

The topographical identification of the brainstem LC neurons was performed using the stereotactic atlas of the rat brain (Fig. 1) [15]. To determine the NA content in the nuclei of neurons (mainly the heterogenous RNA), the $5 \mu \mathrm{m}$ sections were stained in gallocyanine-chrome alum by Einarson [16] and mounted with Eukitt (O. Kindler GmbH \& Co, Freiburg, Germany) (Fig. 2).

The study of sections stained for NA was performed in visible spectrum on the Axiolmager-M2 microscope (Carl Zeiss, Germany). The images taken with the $\mathrm{COHU}$ 4922 (COHU Inc., USA) sensitive camera were recorded as a computer file. The interactive mode was used to identify nucleus-containing neurons and the zone of "interest" whereas automatic calculations helped to find the morphometric and densitometric parameters of the nucleus - its area $\left(\mu \mathrm{m}^{2}\right)$ and optical density of NA(Uif), which characterizes the NA content in the cell nucleus section, concentration of NA in the nucleus $\left(U i f / \mu m^{2}\right)$, which indirectly reflects the neuron functional activity, were calculated automatically. All these characteristics were determined for each neuron. At least 100 cells from each series were subjected to analysis. Microphotographs of the neurons were processed using the Image $\mathrm{J}$ software.

Statistical analysis. All experimental data obtained were calculated using EXCEL 7.0 (Microsoft Corp., USA) and AtteStat free software package [17]. The arithmetic mean value $(M)$, its variance and the standard error of the mean $(m)$ were calculated for all indicators. Parametric statistical methods (Student t-test for the sample with normal distribution) and non-parametric (Mann-Whitney test for the sample with non-normal distribution) were used to determine the reliability of differences in study results between the experimental and control groups of rats. The differences were considered to be statistically reliable at a value of $P<0.05$ [18].

\section{Results}

The study of morphometric and densitometric characteristics of the LC neurons nuclei has found some peculiarities in the indices of the experimental groups in relation to the control group as well as the differences between the experimental groups of rats with $\mathrm{AH}$ (Table 1, Fig. 2).

Thus, the content of NA in the LC neuron nuclei of SHR was reliably higher by $21.68 \%$ in comparison with the control index. At the same time, the opposite dynamics was revealed in rats with ESH in relation to control animals, namely a reliable $14.23 \%$.decrease in the nuclear NA content. The difference in NA content between the experimental groups was $29.51 \%$ less in the rats with ESH than in the SHR group (Table 1).

As for the area of LC neurons nuclei, there were no reliable changes in SHR compared to the control group, while in the rats with $\mathrm{ESH}$ a reliable $12.65 \%$ decrease in the nucleus area was observed. There was no reliable difference between the experimental groups (Table 1).

The NA concentration in the nuclei of $L C$ neurons was also reliably $33.38 \%$ higher only in the SHR compared to the control index while in the rats with ESH there was no significant difference with the control animals. There 
Table 1. Morphometric and densitometric indices of the brainstem LC neurons nuclei in rats of the experimental groups $(\mathrm{M} \pm \mathrm{m})$

\begin{tabular}{l|l|l|l|}
\hline Group of rats / Characteristic under study & $\begin{array}{l}\text { Control } \\
(\mathbf{n}=1 \mathbf{0})\end{array}$ & $\begin{array}{l}\text { SHR } \\
(\mathbf{n}=\mathbf{1 0})\end{array}$ & $\begin{array}{l}\text { ESH } \\
(\mathbf{n}=10)\end{array}$ \\
\hline NA content (Uif) & $21.36 \pm 0.59$ & $0.99 \pm 1.16^{*}$ \\
NA concentration $\left(\right.$ Uif $\left./ \mu m^{2}\right)$ & $0.33 \pm 0.03$ & $0.44 \pm 0.04^{*}$ \\
\hline Nuclear area $\left(\mu \mathrm{m}^{2}\right)$ & $70.14 \pm 1.87$ & $65.92 \pm 2.62$ \\
\hline
\end{tabular}

*: indicates a significant difference in the parameters $(\mathrm{P}<0.05)$ of the experimental group rats relative to the control; \#: indicates a reliable difference in the parameters

$(\mathrm{P}<0.05)$ between rats of the experimental groups with $\mathrm{AH}$.

was a reliable difference between indices of the $\mathrm{AH}$ groups. In the SHR the NA concentration in the nuclei of LC neurons was $19.3 \%$ higher compared to the rats with ESH (Table 1).

\section{Discussion}

The results of these studies suggest that such differences in the morphometric and densitometric indices of the LC neurons nuclei of the experimental rats have resulted from different pathogenetic peculiarities of the $\mathrm{AH}$ development and course in SHR (known as a model of essential hypertension) and in the endocrine-salt model of symptomatic $\mathrm{AH}$. The results obtained are supported by other studies. I. Kourtesis et al. have showed the significantly increased number of noradrenergic granules and their size in the LC neurons of SHR as compared to rats with normal $\mathrm{BP}$, which proves this structure neurons activation in essential $\mathrm{AH}$ [19]. Concerning the indices of rats with induced symptomatic ESH, which significantly differed from the previous model, it should be noted that the induction was performed by repeated injections of prednisolone, which has a cortisol-like effect and causes a clinical manifestation of hypercorticism. It has already been demonstrated that chronic hypercorticism leads to a decrease in the content of biogenic amines, including norepinephrine (NE), in the brain [20]. The researchers explained that mainly by the increased monoamine oxidase-A (MAO-A) activity which accelerates the NE degradation. The fact of feedback between NE and cortisol has turned out to be interesting: a decrease in the content of $\mathrm{NE}$ increases the level of cortisol [21]. In other words, in this situation we observe the classic pathophysiological circulus vitiosus.

Taking into account other links of the ESH pathogenesis - hypernatremia and hypervolemia, it is worth pointing out that Svensson et al. have found by electrophysiological methods that the activity of LC neurons decreases with an increase in circulating blood volume. The researchers have explained that by the increasing activity of vagal afferents and atrial receptors, they also have shown that rat LC single neurons can correspondingly respond to even minor blood volume fluctuations, also suggesting that this structure is involved in circulating blood volume regulation [22].

To sum up, the possible decrease in the LC activity, as the primary source of NE in the brain, could be due to a high level of cortisol and a simultaneous increase in the inhibitory structures activity. Turning to our study, we see that the decrease in the NA content and the nuclear area of LC neurons in rats with ESH are in logical agreement with the results obtained by other researchers.

\section{Conclusions}

Based on the results of our study, the following conclusions can be made:

1. Morphometric and densitometric characteristics of the of the brain stem LC in AH depend on the etiological factor and pathogenesis of hypertension.

2. In essential AH of SHR there is a high synthetic activity in the brainstem LC neurons nuclei along with an increase in the content and concentration of NA.

3. In symptomatic $\mathrm{AH}$ in rats with $\mathrm{ESH}$, on the contrary, the structure activity is decreased and characterized by the reduction in nucleus size and NA content in it.

\section{Funding}

The study is funded as a part of scientific research work at Zaporizhzhia State Medical University "The role of peptidergic structures of hypothalamus and brain stem in the pathogenesis of arterial hypertension", number of state registration 0117U002579 (2017-2019).

Conflicts of interest: authors have no conflict of interest to declare. Конфмікт інтересів: віАсутній.

НаАійшла Ао реАакції / Received: 07.11.2018

Після Аоопрацювання / Revised: 26.11.2018

Прийнято Ао Аруку / Accepted: 06.12.2018

Information about authors:

Hancheva O. V., MD, PhD, DSc, Professor, Head

of the Pathological Physiology Department, Zaporizhzhia State Medical University, Ukraine.

Danukalo M. V., MD, Assistant of the Pathological Physiology Department, Zaporizhzhia State Medical University, Ukraine. Melnikova 0. V., MD, PhD, Associate Professor of the Pathological Physiology Department, Zaporizhzhia State Medical University, Ukraine.

Відомості про авторів:

Ганчева О. В., А-р меА. наук, професор, зав. каф. патологічної фізіології, Запорізький Аержавний медичний університет, Україна.

Аанукало М. В., асистент каф. патологічної фізіології, Запорізький Аержавний медичний університет, Україна. Мельнікова О. В. канА. меА. наук, Аоцент каф. патологічної фізіології, Запорізький державний медичний університет, Україна.

\section{Сведения об авторах:}

Ганчева О. В., А-р меА. наук, профессор,

зав. каф. патологической физиологии, Запорожский государственный медицинский университет, Украина. Аанукало М. В., ассистент каф. патологической физиологии, Запорожский государственный медицинский университет, Украина.

Мельникова О. В. канА. МеА. наук, Аоцент каф. патологической физиологии, Запорожский государственный медицинский университет, Украина. 
References

[1] Swischenko, E., Bahrii, A. E., Yena, L. M., Kovalenko, V. M., Koval, S. M., Mellina, I. M., et al. (2012). Arterialna hipertenziia. Onovlena ta adaptovana klinichna nastanova, zasnovana na dokazakh [Arterial hypertension. An updated and adapted clinical guideline based on evidence]. Novosti mediciny i farmacii, 12(422), 24-31. [in Ukrainian].

[2] Perez, H., Ruiz, S., Nunez, H., White, A., Gotteland, M., \& Hernandez, A. (2006). Paraventricular-coerulear interactions: role in hypertension induced by prenatal undernutrition in the rat. European Journal of Neuroscience, 24(4), 1209-1219. doi: 10.1111/j.14609568.2006.04997.x

[3] Chertok, V. M., \& Kotsyuba, A. E. (2015). Norepinephrinergic and nitroxidergic neurons of vasomotor nuclei in hypertensive rats. Bulletin of experimental biology and medicine, 158(5), 695-699. doi: 10.1007/ s10517-015-2838-4

[4] Kotsiuba, A. E., Chertok, V. M., \& Babich, E. V. (2010). Nitroksidergicheskie nejrony bul'barnogo vazomotornogo centra pri arterial'noj gipertenzii [Nitricoxideergic neurons of the human bulbar vasomotor center in arterial hypertension]. Zhurnal nevrologii i psikhiatrii im. C.C. Korsakova, 110(2), 61-65. [in Russian].

[5] Feinstein, D. L., Kalinin, S., \& Braun, D. (2016). Causes, consequences, and cures for neuroinflammation mediated via the locus coeruleus: noradrenergic signaling system. Journal of neurochemistry, 139(2), 154-178. doi: 10.1111/jnc.13447

[6] Aston-Jones, G., \& Waterhouse, B. (2016). Locus coeruleus: from global projection system to adaptive regulation of behavior. Brain research, 1645, 75-8. doi: 10.1016/j.brainres.2016.03.001

[7] Samuels, E. R., \& Szabadi, E. (2008). Functional neuroanatomy of the noradrenergic locus coeruleus: its roles in the regulation of arousal and autonomic function part I: principles of functional organisation. Current neuropharmacology, 6(3), 235-53. doi: 10.2174/157015908785777229

[8] O'Donnell, J., Zeppenfeld, D., McConnell, E., Pena, S., \& Nedergaard, M. (2012). Norepinephrine: a neuromodulator that boosts the function of multiple cell types to optimize CNS performance. Neurochemical research, 37(11), 2496-512. doi: 10.1007/s11064-0120818-x

[9] Wood, C. S., Valentino, R. J., \& Wood, S. K. (2017). Individual differences in the locus coeruleus-norepinephrine system: Relevance to stress-induced cardiovascular vulnerability. Physiology \& behavior, 172, 40-48. doi: 10.1016/j.physbeh.2016.07.008

[10] Wang, X., Piñol, R. A., Byrne, P., \& Mendelowitz, D. (2014). Optogenetic stimulation of locus ceruleus neurons augments inhibitory transmission to parasympathetic cardiac vagal neurons via activation of brainstem $\alpha 1$ and $\beta 1$ receptors. Journal of Neuroscience, 34(18), 6182-9. doi: 10.1523/JNEUROSCI.5093-13.2014

[11] Tverskoy, A. V., Dolzhikov, A. A., Bobintsev, I. I., Kryukov, A. A., \& Belykh, A. E. (2014). Morfologicheskiye izmeneniya neyronov oblastey CA1 i CA3 gippokampa krys pri hronicheskom immobilizacyonnom stresse (morfometricheskoye issledovanie) [Morphological changes of CA1 and CA3 hippocampal regions in rats under chronic immobilization stress (morphometric study)]. Kurskij nauchno-prakticheskij vestnik "Chelovek i ego zdorov'e", 3, 37-41. [in Russian].

[12] Kadzharyan, E. V. (2013) Osobennosti funcional'nogo sostoyaniya beta-e'ndorfin synteziruyuschikh nejronov paraventricularnogo yadra hipotalamusa krys v norme i pri e'ksperimental'nom sakharnom diabete [The peculiarities of the functional state of beta-endorphinsynthesizing neurons of the paraventricular nucleus of rats' hypothalamus in normal conditions and with experimental diabetes mellitus]. Perspektyvy medytsyny ta biolohii, 5(1), 78-82. [in Russian]

[13] Camacho, P., Fan, H., Liu, Z., \& He, J. Q. (2016). Small mammalian animal models of heart disease. American journal of cardiovascular disease, 6(3), 70-80.

[14] Kolesnyk, Yu. M., Hancheva, O. V., Abramov, A. V., Ivanenko, T. V., Tischenko, S. V., Kuzo, N. (patentee) (2015). Patent 102234 Ukraina, MPK G09V 23/28. Sposib modeliuvannia symptomatychnoi arterialnoi hipertezii u dribnykh hryzuniv [Patent 102234 Ukraine, IPC G09V 23/28. Method of simulation of symptomatic arterial hypertension in small rodents]. Bulleten, 20. [in Ukrainian].

[15] Paxinos, G., \& Watson, C. H. (1986). Atlas of the rat brain in stereotaxic coordinates. Academic, New York.

[16] Pearse, A. G. E. (1962). Gistokhimiya. Teoreticheskaya i prikladnaya [Histochemistry, Theoretical and Applied]. Moscow: Izdatel'stvo inostrannoy literatyri. [in Russian].

[17] Gajdyshev, I. P. (2015). Modelirovanie stokhasticheskikh i determinirovannykh sistem: rukovodtvo pol'zovatelya programmy AtteStat [Modeling Stochastic and Deterministic Systems: AtteStat Software User Guide]. Kurgan. [in Russian].

[18] Zajcev, V. M., Liflyandskij, V. G., \& Marinkin, V. I. (2006). Prikladnaya medicinskaya statistika [Applied medical statistics]. Saint Petersburg: Foliant. [in Russian].
[19] Kourtesis, I., Kasparov, S., Verkade, P., \& Teschemacher, A. G. (2015). Ultrastructural correlates of enhanced norepinephrine and neuropeptide $\mathrm{Y}$ cotransmission in the spontaneously hypertensive rat brain. $A S N$ Neuro, 7(5), pii: 1759091415610115 . doi: $10.1177 / 1759091415610115$

[20] Bliss, E. L., \& Zwanziger, J. (1966). Brain amines and emotional stress. Journal of psychiatric research, 4(3), 189-198.

[21] Uzbekov, M. G. (2005). Nejrokhimicheskie aspekty vzaimosvyazi monoaninergicheskikh i gormonal'nykh sistem $v$ patogeneze trevozhnoj depressii [Neurochemical aspects of the relationship between monoaminergic and hormonal systems in the pathogenesis of anxious depression]. Social 'naya i klinicheskaya psikhiatriya, 15(2), 108-110. [in Russian].

[22] Svensson, T. H., \& Thoren, P. (1979). Brain noradrenergic neurons in the locus coeruleus: inhibition by blood volume load through vagal afferents. Brain Research, 172(1), 174-178. https://doi.org/10.1016/00068993(79)90908-9 